\title{
Hubungan Sepsis Neonatorum dengan Berat Badan Lahir pada Bayi di RSUP Dr. M. Djamil Padang
}

\author{
Putri Rahmawati ${ }^{1}$, Mayetti $^{2}$,Sukri Rahman ${ }^{3}$
}

\begin{abstract}
Abstrak
Sepsis neonatorum merupakan salah satu penyakit yang masih menjadi masalah utama pada neonatus saat ini, karena banyaknya faktor risiko yang belum dapat dicegah.Salah satu faktor risiko tersebut adalah berat badan lahir rendah atau lebih. Tujuan penelitian ini adalah menentukan hubungan sepsis neonatorum dengan berat badan lahir pada bayi di RSUP Dr. M. Djamil Padang. Jenis penelitian ini adalah analitik retrospektif dengan metode case control study. Populasi adalah seluruh neonatus yang mengalami sepsis neonatorum (kasus) dan yang tidak mengalami sepsis neonatorum (kontrol) yang diambil dari data rekam medik RSUP.Dr. M. Djamil Padang periode Januari 2014 sampai Juli 2016. Subjek penelitian adalah populasi dengan data rekam medik yang lengkap. Hasil penelitian diolah dengan uji Chi-square. Jumlah subjek penelitian adalah 162 orang yang terdiri dari 81 kasus dan 81 kontrol. Dari 81 neonatus yang mengalami sepsis neonatorum, 43 diantaranya mengalami sepsis dengan late onset sepsis, 38 dengan early onset sepsis, 25 dengan Berat Badan Lahir Rendah (BBLR) dan 56 tidak BBLR. Setelah dilakukan uji hubungan antara sepsis neonatorum dengan berat badan lahir menggunakan uji Chi-square didapatkan nilai $p=0,601, O R=1,276$, $\mathrm{Cl}=0,643-2,530$. Simpulan studi ini ialah tidak terdapat hubungan yang bermakna antara sepsis neonatorum dengan berat badan lahir bayi. BBLR memiliki risiko yang lebih besar untuk mengalami sepsis daripada yang tidak BBLR.
\end{abstract}

Kata kunci: sepsis neonatorum, berat badan lahir, early onset sepsis, late onset sepsis

\section{Abstract}

Neonatal sepsis is one of diseases that has been becoming the main problem to neonates nowadays, because there are many risk factors which have not been able to be prevented and solved yet. Some of the factors are low and high birth weight. The objective of this study was to determine association between neonatal sepsis and infant birth weight at RSUP Dr. M.Djamil Padang. This research was an retrospective analitic one using case control study as the method. The population were all neonates with sepsis (cases) and without sepsis ( controls) that were taken from medical records in Dr. M. Djamil Padang Hospital from January 2014 to July 2016. The research subjects were population with complete medical records. The result has been processed by Chi-square test. There were 162 subjects, consisted 81 cases and 81 controls, Among 81 neonates with neonatal sepsis, there were 43 with late onset sepsis, 38 with early onset sepsis, then 25 neonates with low birth weight and 56 without low birth weight. By proceeding the test to get association between neonatal sepsis and birth weight, the result was revealed as $p=0,601$, $O R=1,276, C l=0,643-2,530$. The conclusion is no significant association between neonatal sepsis and birth weight. Low birth weight infant has the bigger risk to get sepsis compared to non low birth weight infant.

Keywords: neonatal sepsis, birth weight, early onset sepsis, late onset sepsis

Affiliasi penulis: 1. Prodi Kedokteran Fakultas Kedokteran Universitas Andalas Padang (FK Unand), 2. Bagian IImu Kesehatan Anak FK Unand/RSUP Dr. M.Djamil padang 3 Bagian THT-KL FK Unand

Korespondensi: Putri Rahmawati,,

Email:putrirahmawati647@gmail.com Telp: 082382870428

\section{PENDAHULUAN}

Status kesehatan bayi merupakan salah satu indikator yang sensitif untuk menilai kesehatan masyarakat di suatu negara. Profil Kesehatan Indonesia tahun 2014 menunjukkan bahwa Angka 
Kematian Bayi (AKB) di Indonesia pada tahun 2012 adalah 32 per 1000 kelahiran hidup, sedangkan target Millenium Development Goals (MDGs) 2015 adalah menurunkan AKB menjadi 23 per 1000 kelahiran hidup. ${ }^{1}$ Di kota Padang, AKB pada tahun 2014 tercatat 168 dari 17201 jumlah kelahiran. ${ }^{2}$ Masa yang paling rentan dari sepanjang kehidupan bayi adalah periode neonatal, dalam laporan World Health Organization (WHO) dikemukakan bahwa terdapat empat juta kematian neonatus setiap tahunnya, sepertiga dari penyebab kematian tersebut disebabkan oleh infeksi berat dan seperempatnya atau sekitar satu jutanya karena sepsis neonatorum. ${ }^{3}$

Sepsis neonatorum sebagai salah satu bentuk penyakit infeksi pada neonatus masih merupakan masalah utama yang belum dapat terpecahkan sampai saat ini. Sepsis neonatorum adalah Systemic Inflammation Respons Syndrome (SIRS) yang disertai dengan infeksi yang telah terbukti (proven infection) atau tersangka (suspected infection) yang terjadi pada bayi dalam satu bulan pertama kehidupan. ${ }^{4}$ SIRS merupakan kaskade inflamasi yang diawali oleh respon host terhadap faktor infeksi dan bukan infeksi berupa suhu, denyut jantung, respirasi dan jumlah leukosit. $^{5,6}$

Kejadian sepsis dipengaruhi oleh berbagai faktor seperti faktor ibu (kelahiran kurang bulan, persalinan dengan tindakan, demam pada ibu), faktor lingkungan, serta yang paling penting faktor dari neonatus sendiri, seperti jenis kelamin, status kembar, prosedur invasif, bayi kurang bulan dan berat badan lahir. ${ }^{7}$ Faktor risiko terjadinya sepsis adalah bayi dengan jenis kelamin laki-laki, karena aktivitas pada bayi laki-laki lebih tinggi dibandingkan bayi perempuan sehingga bayi laki-laki memerlukan oksigen yang lebih banyak, karena jika oksigen kurang di dalam tubuh maka bakteri anaerob akan mudah berkembang. Status kembar juga merupakan salah satu faktor risiko, karena bayi kembar kemungkinan besar akan lahir dengan Berat Badan Lahir Rendah (BBLR) dan prematuritas, sehingga akan berisiko mengalami sepsis karena organ tubuhnya belum sempurna dan sistem imunnya kurang yang menyebabkan mudah terkena infeksi. ${ }^{8}$
Faktor lain yang paling banyak adalah berat badan lahir bayi, bayi yang lahir dengan BBLR atau Berat Badan Lahir Lebih (BBLL) memiliki risiko yang lebih besar untuk mengalami masalah. Pada bayi BBLR terutama dengan prematuritas pematangan organ tubuhnya (hati, paru, enzim, pencernaan, otak, daya pertahanan tubuh terhadap infeksi) belum sempurna, maka bayi BBLR sering mengalami komplikasi yang berakhir dengan kematian. Bayi yang lahir dengan berat badan normal akan mengalami penurunan berat badan pada minggu pertama setelah lahir, namun akan mengalami peningkatan seiring dengan pertumbuhan bayi. Pada BBLR menurunnya berat badan bayi dapat terjadi setiap saat, karena biasanya akan ada masalah pada pemberian Air Susu Ibu (ASI), kurang atau tidak mampunyai bayi menghisap ASI juga menjadi risiko mudahnya terkena infeksi, hal ini disebabkan kurangnya nutrisi dan immunoglobulin yang didapat bayi dari ASI. Pada BBLR pusat pengaturan pernafasan belum sempurna, otot pernafasan dan tulang iga masih lemah yang mengakibatkan oksigen yang masuk ke otak kurang, jika oksigen kurang maka kuman anaerob mudah berkembang yang menyebabkan mudah terjadi infeksi. ${ }^{8,9}$ Pada bayi berat lahir amat rendah $(<1000 \mathrm{~g})$ kejadian sepsis terjadi sekitar 26/1000 kelahiran dan berbeda dengan bayi berat lahir antara 1000-2000g yang angka kejadiannya antar 8-9/1000 kelahiran. ${ }^{10}$

Berdasarkan hasil penelitian yang dilakukan oleh Rizky Wirawan di RSUD Dr. Moewardi Surakarta pada tahun 2012 menemukan bahwa terdapat hubungan antara berat badan lahir dengan terjadinya sepsis neonatorum yaitu BBLR memiliki risiko sebesar tiga kali untuk mengalami sepsis dari pada yang tidak BBLR. BBLR berisiko mengalami sepsis neonatorum karena pada bayi dengan BBLR pematangan organ tubuhnya belum sempurna. ${ }^{11}$ Ini berbeda dengan penelitian yang dilakukan oleh Carolus et al di Sub Bagian Neonatal RSUP Prof. Dr. R. D. Kondou Manado tahun 2012 - 2013 bahwa tidak ada hubungan antara berat badan lahir dalam bentuk kategori rendah dan normal dengan kejadian sepsis neonatorum, tetapi dari tabel diperoleh bayi yang mengalami sepsis memiliki berat badan lahir rendah lebih banyak dengan 
persentase $85,7 \%$. $^{12}$ Berdasarkan permasalahan di atas maka perlu diteliti apakah sepsis neonatorum dipengaruhi oleh berat badan lahir bayi di RSUP Dr. M. Djamil Padang.

\section{METODE}

Penelitian ini adalah analitik dengan metode case control study, dasar pengambilan subjek dimulai dari identifikasi kelompok sepsis neonatorum (kasus) dan kelompok yang tidak mengalami sepsis neonatorum (kontrol) untuk kemudian dilihat hubungannya dengan berat badan lahir pada neonatus dengan memanfaatkan data sekunder berupa catatan medik. Penelitian ini telah dilakukan di Rekam Medik RSUP Dr. M. Djamil Padang pada bulan Januari 2016-Januari 2017. Jumlah sampel pada penelitian ini 81 sampel yang mengalami sepsis neonatorum sebagai kasus dan 81 sampel yang tidak mengalami sepsis neonatorum sebagai kontrol yang diambil dari data pasien yang dirawat pada bulan Januari 2014 Juli 2016. Sampel diambil menggunakan teknik consecutive sampling yaitu semua sampel yang ada dan memenuhi kriteria inklusi penelitian dimasukkan ke dalam penelitian sampai jumlah yang diperlukan terpenuhi yang diambil dari catatan medik bayi penderita sepsis neonatorum periode Januari 2014- Juli 2016. Kriteria inklusi kasus adalah neonatus yang menderita sepsis neonatorum dengan data rekam medik yang lengkap, kriteria inklusi kontrol adalah neonatus yang tidak mengalami sepsis neonatorum, sedangkan kriteria eksklusi adalah neonatus dengan data rekam medik tidak lengkap.Variabel penelitian yang diteliti adalah sepsis neonatorum, berat badan lahir bayi. Data yang didapat dianalisis dengan uji Chi-square secara komputerisasi. Dikatakan berhubungan signifikan antara sepsis neonatorum dengan berat badan lahir bayi apabila $p<0,05$.

\section{HASIL}

Hasil studi memperlihatkan bahwa dari 81 subjek kasus sepsis neonatorum $58,0 \%$ berjenis kelamin laki-laki, sebagian besar subjek penelitian berasal dari ibu dengan kehamilan aterm (77,2\%), sedangkan ditinjau dari jenis persalinannya 50,6\% lahir dengan tindakan.
Tabel 1. Distribusi frekuensi sepsis neonatorum berdasarkan onset sepsis

\begin{tabular}{lll}
\hline $\begin{array}{l}\text { Onset Sepsis } \\
\text { Neonatorum }\end{array}$ & $\mathbf{n}$ & $\%$ \\
\hline Early onset sepsis & 38 & 46,91 \\
Late onset sepsis & 43 & 53,09 \\
\hline Jumlah & 81 & 100 \\
\hline
\end{tabular}

Tabel 1 menunjukkan bahwa angka kejadian late onset sepsis lebih banyak dari pada early onset sepsis.

Tabel 2. Hubungan sepsis neonatorum dengan berat badan lahir pada bayi

\begin{tabular}{lccccc}
\hline $\begin{array}{l}\text { Berat } \\
\text { Badan } \\
\text { Lahir }\end{array}$ & \multicolumn{2}{c}{ Sepsis } & \multicolumn{2}{c}{$\begin{array}{c}\text { Tidak } \\
\text { Sepsis }\end{array}$} & p \\
\cline { 2 - 4 } & $\mathbf{n}$ & $\%$ & $\mathbf{n}$ & $\%$ & \\
\hline BBLR & 25 & 30,9 & 21 & 25,9 & 0,601 \\
Tidak BBLR & 56 & 69,1 & 60 & 74,1 & \\
\hline Jumlah & 81 & 100,0 & 81 & 100,0 & \\
\hline
\end{tabular}

$\mathrm{BBLR}=$ Berat Badan Lahir Rendah

Berdasarkan Tabel 2 diketahui bahwa pada kelompok sepsis ternyata lebih banyak yang memiliki berat badan lahir rendah dibandingkan dengan kelompok yang tidak sepsis $(30,9 \%$ vs $25,9 \%)$, tapi setelah uji statistik, ternyata tidak ada hubungan yang bermakna antara sepsis neonatorum dengan berat badan lahir pada bayi ( $p=0,601)$. Jika dilihat dari nilai Odds Ratio (OR) didapatkan nilai $\mathrm{OR}=1,276$ dengan confidence interval $(0,643-2,530)$ yang artinya BBLR lebih berisiko untuk mengalami sepsis neonatorum dibandingkan yang tidak BBLR.

\section{PEMBAHASAN}

Penelitian ini dilakukan dengan melihat data rekam medik pasien yang mengalami sepsis neonatorum di RSUP Dr. M. Djamil Padang. Jumlah sampel pada penelitian ini sebanyak 81 subjek kasus, dengan jumlah laki-laki 47 orang $(58,0 \%)$ dan perempuan 34 orang $(42,0 \%)$. Hasil penelitian ini sesuai dengan penelitian yang dilakukan oleh Simbolon (2006) yang mendapatkan kejadian sepsis neonatorum lebih banyak pada laki-laki $(51,8 \%)$, hal ini dipengaruhi oleh faktor terkait seks dan kerentanan hospes. ${ }^{8}$ Bayi laki-laki lebih banyak mengalami sepsis neonatorum karena aktivitas pada bayi laki-laki lebih 
tinggi dibandingkan bayi perempuan, sehingga bayi laki-laki memerlukan oksigen lebih banyak, sementara pada bayi BBLR terutama dengan prematuritas pusat pengaturan pernafasan belum sempurna, otot pernafasan dan tulang iga masih lemah yang mengakibatkan oksigen yang seharusnya dibutuhkan lebih banyak akan kurang, jika oksigen kurang maka kuman anaerob mudah berkembang yang menyebabkan mudah terjadi infeksi. ${ }^{8}$

Sepsis neonatorum lebih banyak lahir dari ibu dengan usia kehamilan preterm dibandingkan yang tidak sepsis $(22,8 \%$ vs $22,2 \%)$. Hasil ini sejalan dengan penelitian yang dilakukan oleh Riskawa et al (2012), bahwa salah satu faktor yang menyebabkan sepsis neonatorum adalah usia kehamilan yang preterm (< 37 minggu) karena pada bayi prematur pematangan organ tubuhnya belum sempurna, kadar imunoglobulin serum yang lebih rendah, ketidakmatangan kulit yang melemahkan pertahanan imunitas bayi, belum sempurnanya fungsi sekretori IgA di mukosa usus yang merupakan lapisan pelindung terhadap invasi bakteri usus dan juga respon imun adaptif terhadap berbagai patogen masih belum sempurna. $^{13}$

Bayi yang mengalami sepsis neonatorum lebih banyak lahir dengan tindakan (seksio sesarea, ekstraksi vakum, ekstraksi forceps) yaitu sebanyak $(50,6 \%)$ dibandingkan yang lahir spontan. Hal ini sejalan dengan penelitian yang dilakukan oleh Lihawa et al, 2013 yang menyatakan bahwa bayi yang lahir dengan tindakan lebih berisiko untuk terjadi sepsis neonatorum. Hal ini terjadi karena kontaminasi bakteri melalui alat-alat bantu dalam persalinan yang tidak steril. ${ }^{14}$ Jika dibandingkan dengan kontrol, bayi yang mengalami sepsis lebih sedikit yang lahir dengan tindakan dibandingkan yang tidak sepsis $(50,6 \%$ vs $64,2 \%$ ), hal ini mungkin dipengaruhi oleh faktor-faktor ataupun penyakit lain yang menjadi indikasi pasien tersebut untuk dilakukan tindakan dimana penyakitnya diabaikan pada pasien yang tidak sepsis.

\section{Distribusi Frekuensi Sepsis Neonatorum Di RSUP Dr. M. Djamil Padang}

Berdasarkan hasil penelitian pada Tabel 1 diketahui bahwa angka kejadian late onset sepsis neonatorum lebih banyak dibandingkan early onset, dapat dijelaskan bahwa perbedaan antara early onset dan late onset sepsis hanya dari segi waktu paparan kuman dan macam kuman penyebabnya. ${ }^{7}$

Early onset sepsis ditemukan pada hari-hari pertama kehidupan (72 jam pertama), infeksi terjadi secara vertikal karena penyakit ibu dan infeksi yang diderita ibu selama kehamilan, persalinan atau kelahiran. Faktor risiko pada early onset sepsis dapat dikelompokkan menjadi faktor ibu (persalinan dan kelahiran kurang bulan, ketuban pecah lebih dari 1824 jam, chorioamnionitis, persalinan dengan tindakan, demam pada ibu ( $>38,4^{\circ} \mathrm{C}$ ), infeksi saluran kencing pada ibu, faktor sosial ekonomi dan gizi ibu) dan faktor bayi (asfiksia perinatal, berat lahir rendah, bayi kurang bulan, prosedur invasif, kelainan bawaan). ${ }^{7}$

Late onset sepsis disebabkan oleh kuman yang berasal dari lingkungan di sekitar bayi setelah 72 jam pertama lahir. Proses infeksi ini disebut juga infeksi dengan transmisi horizontal dan termasuk di dalamnya infeksi karena kuman nosokomial. Keadaan ini sering ditemukan pada bayi yang dirawat di ruang intensif bayi baru lahir, bayi kurang bulan yang mengalami lama rawat, nutrisi parenteral yang berlarut-larut, infeksi yang bersumber dari alat perawatan bayi, infeksi nosokomial atau infeksi silang dari bayi lain atau dari tenaga medik yang merawat bayi. ${ }^{7}$

\section{Gambaran Berat Badan Lahir Pada Bayi Yang Mengalami Sepsis Neonatorum Di RSUP Dr. M. Djamil Padang}

Didapatkan jumlah sepsis neonatorum paling banyak $(69,1 \%)$ pada bayi dengan berat badan lahir tidak BBLR (>2500gram), dimana 95\% didominasi oleh berat lahir normal, namun dibandingkan dengan kontrol, ternyata kelompok sepsis lebih banyak memiliki BBLR dibandingkan dengan kelompok yang tidak mengalami sepsis neonatorum (30,9\% vs $25,9 \%)$ ini sejalan dengan penelitian Carolus et al (2013) yang mendapatkan bahwa bayi dengan sepsis memiliki berat badan lahir rendah lebih banyak $(85,7 \%)$, hal ini disebabkan karena pusat pengatur pernafasan belum sempurna, surfaktan paru-paru masih kurang, sehingga perkembangannya tidak sempurna, otot pernafasan dan tulang iga masih lemah yang akan 
mengakibatkan oksigen masuk ke otak kurang, jika oksigen (02) kurang maka kuman anaerob mudah berkembang menyebabkan mudah terjadi infeksi. ${ }^{12}$

\section{Hubungan Kejadian Sepsis Neonatorum Dengan Berat Badan Lahir Bayi Di RSUP Dr. M. Djamil Padang}

Hasil analisis uji statistik menggunakan uji Chisquare karena skala kedua variabel adalah nominal. Berdasarkan Tabel 2 tidak didapatkan nilai signifikan antara hubungan sepsis neonatorum dengan berat badan lahir dalam kategori BBLR dan tidak BBLR $(p=0,601)$ yang berarti $p>0,05$, sehingga hipotesis yang menyatakan "terdapat hubungan sepsis neonatorum dengan berat badan lahir" ditolak dan tidak memiliki hubungan yang bermakna, namun dilihat dari Odds Ratio didapatkan nilai $\mathrm{OR}=1,276$ dengan confidence interval $(0,643-2,530)$ yang berarti bahwa BBLR lebih berisiko untuk terjadi sepsis neonatorum dibandingkan tidak BBLR.

Hasil penelitian ini sejalan dengan yang telah dilakukan oleh Carolus et al (2013) yang menyatakan tidak ada hubungan antara berat badan lahir dalam bentuk kategori rendah dan normal dengan kejadian sepsis neonatorum, tetapi dari Tabel 2 diperoleh bayi yang mengalami sepsis memiliki berat badan lahir rendah lebih banyak, hal ini tidak berhubungan karena bisa dipengaruhi oleh faktor lain yang menyebabkan terjadinya sepsis seperti faktor dari ibu (obstetrik) atau tanda-tanda koriamnionitis seperti ketuban pecah lama $\left(>18\right.$ jam), demam intrapartum ibu $\left(>38,4^{\circ} \mathrm{C}\right)$, leukositosis ibu, infeksi saluran kencing pada ibu, faktor sosial ekonomi dan gizi ibu, selain itu juga dapat dipengaruhi oleh faktor lingkungan yang disebut dengan infeksi dengan transmisi horizontal dan termasuk didalamnya infeksi karena kuman nosokomial. $^{12}$

Penelitian ini sesuai dengan pendapat yang mengatakan bahwa BBLR ataupun berat badan tidak normal lebih banyak menderita sepsis neonatorum. BBLR lebih rentan untuk terkena infeksi terutama pada BBLR dengan prematuritas karena kadar imunoglobulin serum yang lebih rendah, ketidak matangan kulit yang melemahkan pertahanan imunitas bayi, belum sempurnanya fungsi sekretori IgA di mukosa usus yang merupakan lapisan pelindung terhadap invasi bakteri di usus, dan respon imun adaptif terhadap berbagai patogen masih belum sempurna. $^{13}$

Secara normal pertahanan tubuh terhadap agen infeksi selalu melewati kombinasi penghalang fisik, termasuk kulit, membran mukosa, lapisan mukosa dan sel epitel bersilia (mekanisme pertahanan non spesifik) serta berbagai komponen sistem imun (mekanisme pertahanan spesifik). Komponen sistem imun ini terdiri atas sel-sel T, B dan natural killer, sel fagosit dan protein-protein komplemen. Selain itu juga akan dihasilkan lima isotipe imunoglobulin ( IgG, IgM, $\lg A, \lg E, \lg D)$ untuk proteksi terhadap agen infeksi. ${ }^{15}$

IgG ada dalam semua cairan tubuh, dimana janin mulai mendapat sejumlah IgG ibu yang berarti melalui transplasenta pada sekitar usia kehamilan 12 minggu, dan jumlahnya naik secara mantap sampai pada saat lahir. Antibodi IgG yang diturunkan ibu cukup berperan sebagai opsonin stabil-panas pada kebanyakan bakteri gram positif, dan antibodi $\lg G$ terhadap virus memberikan proteksi yang cukup terhadap agen-agen tersebut. Pada bayi prematur yang cendrung BBLR mendapatkan lebih sedikit IgG ibu pada saat lahir dibandingkan dengan dengan bayi cukup bulan, sehingga aktivitas opsonik serumnya lebih rendah untuk semua tipe organisme yang akan meningkatkan risiko BBLR untuk terkena infeksi. ${ }^{15}$

IgA merupakan imunoglobulin protektif utama sekresi eksterna yaitu sekresi saluran gastrointestinal, respirasi, dan urogenital, tetapi juga ada dalam sirkulasi. IgA bisa diproduksi oleh kelenjer mamae. Kelenjer mamae adalah bagian dari integral sistim imun mukosa, limfosit yang terlihat di kelenjar mamae berasal dari BALT atau GALT. Antibodi ASI ini diperlukan untuk melawan agen infeksius dari lingkungan ibu, dimana mukosa merupakan tempat tersering masuknya agen infeksius. Di pihak lain masa neonatus adalah masa kritis terhadap patogen mukosa karena imaturitas mukosa pada masa ini. ASI akan merangsang pembentukan IgA pada mukosa neonatus, sementara pada bayi yang lahir dengan BBLR sering mengalami masalah pada refleks hisap ASI, sehingga hal tersebut juga akan meningkatkan risiko terjadinya sepsis pada neonatus. ${ }^{16}$ 
Keterbatasan pada penelitian ini ialah terdapat faktor lain yang mempengaruhi terjadinya sepsis tidak dapat dilihat hubungannya karena adanya data yang nol, sehingga beberapa faktor yang kemungkinan berhubungan dengan variabel dependen tidak dapat dianalisis, kemudian untuk penelitian selanjutnya perlu menggunakan sampel yang lebih besar sehingga mendapatkan nilai OR yang lebih presisi.

\section{SIMPULAN}

BBLR lebih berisiko untuk mengalami sepsis dibandingkan yang tidak BBLR, walaupun tidak terdapat hubungan yang bermakna secara statistik.

\section{DAFTAR PUSTAKA}

1. Kementrian Kesehatan RI. Profil kesehatan Indonesia 2014. Jakarta: Departemen Kesehatan RI. 2015.

2. Dinas Kesehatan Kota Padang. Profil kesehatan kota Padang tahun 2014. Padang: Dinas Kesehatan Kota Padang. 2015.

3. World Health Organization (WHO). Neonatal sepsis a major killer to be tackled in communities. World Health Organization Maternal, newborn, child, and adolescent health. 2009 (diunduh Mei 2016). Tersedia dari: http://www.who.int/maternal child adolescent/news events/news/2009/19 01/e $\underline{\mathrm{n} / .}$

4. Goldstein B, Giroir, Randolph A, The members of the internasional consensus conference on pedatric sepsis. Internasional pediatric sepsis consensus conference: definitions for sepsis and organ dysfucton in pediatrics. Pediatr Crit Care Med. 2005;6(1): 2-8

5. Enrione MA, Powell KR. Sepsis, sepstic shock, and systemic inflammatory response syndrome. Dalam: Kliegman RM, Behrman RE, Jenson HB, Stanton BF, editor (penyunting). Nelson textbook of pediatrics. Edisi ke-18. Philadelphia: WB Saunders. 2007.hlm.1094-9.

6. Thomas NJ, Tamburro RF, Hall MW, Rajasekaran $\mathrm{S}$, Venglarcik JS. Bacterial sepsis and mechanisms of microbial pathogeneis. Dalam: Nichols DG, editor (penyunting). Roger's Textbook of Pediatric intensive Care. Edisi ke-4. Baltimore: Lippincott Williams \& Wilkins. 2008.hlm.477-88.
7. Aminullah A. Sepsis pada bayi baru lahir. Dalam: Kosim MS, Yunanto A, Dewi R, Sarosa GI, Usman A, editor (penyunting). Buku ajar neonatologi. Edisi ke-1. Jakarta: Badan Penerbit IDAI. 2008.hlm.17085.

8. Simbolon D. Faktor risiko sepsis pada bayi baru lahir di RSUD Curup Kabupaten Rejang Lebong. (skripsi). Bengkulu: Politeknik Kesehatan Bengkulu; 2006.

9. Kliegman RM. Bayi beresiko tinggi. Dalam: Wahab AS,penterjemah. Nelson ilmu kesehatan anak. Volume 1. Edisi ke-15. Jakarta: EGC. 2000.hlm. 558-73.

10. Damanik SM. Klasifikasi bayi menurut berat lahir dan masa gestasi. Dalam: Kosim MS, Yunanto A, Dewi R, Sarosa GI, Usman A, editor (penyunting). Buku ajar neonatologi. Edisi ke-1. Jakarta: Badan Penerbit IDAI.2008.hlm.11-29.

11. Wirawan R. Hubungan antara bayi berat lahir rendah dengan terjadinya sepsis neonatorum (skripsi). Surakarta: Universitas Muhammadiyah Surakarta; 2012.

12. Carolus W, Rompis J, Wilar R. Hubungan apgar skor dan berat badan lahir dengan sepsis neonatorum (skripsi). Manado: Bagian Ilmu Kesehatan Anak Fakultas Kedokteran Universitas Sam Ratulangi Manado; 2013.

13. Riskawa HK, Hilmanto D, Chairulfatah A. Perbandingan kadar calprotectin serum pada bayi kurang bulan antara sepsis neonatorum dan tanpa sepsis neonatorum. J Indon Med Assoc. 2012;62 (4):127-31

14. Lihawa MY, Mantik M, Wilar R. Hubungan jenis persalinan dengan kejadian sepsis neonatorum di RSUP Prof Dr R D Kandou Manado (skripsi). Manado: Bagian IImu Kesehatan Anak Fakultas Kedokteran Universitas Sam Ratulangi Manado; 2013.

15. Gotoff SP. Sepsis dan meningitis neonatus. Dalam: Wahab AS, penterjemah. Nelson ilmu kesehatan anak .Volume 1. Edisi ke-15. Jakarta: EGC. 2000.hlm.653-5.

16. Akib AAP, Munasir Z, Kurniati N. Buku ajar alergi imunologi anak. Edisi ke-2. Jakarta: Badan Penerbit IDAI. 2010. 